\title{
The influence of temperament on cortisol concentration and metabolic profile in Tsigai lambs
}

\author{
Ferenc Pajor, Alfréd Kovács, János Tőzsér and Péter Póti \\ Institute of Animal Husbandry, Szent István University, Hungary
}

\begin{abstract}
The aim of the present study was to investigate the relationships between temperament score and blood cortisol concentration, as well as energy metabolic parameters (glucose, triglyceride, non-esterified fatty acid and cholesterol) in Tsigai lambs during fattening. The temperament of lambs was assessed (scored) by a temperament score test, where the behaviour of animals was evaluated in a 5-score system (1: calm, 5: nervous) while spending $30 \mathrm{sec}$ on the scale during weighing. Based on temperament scoring at the beginning of fattening 7, 6 and 7 lambs were selected according to temperament categories as calm (1 score 1), intermediate (score 3) and nervous lambs (scores 4 and 5), respectively. At this time, our study did not show any correlation between temperament score, blood cortisol concentration and the metabolic profile. However, at the end of fattening, the calmer lambs had lower cortisol concentrations $(2.60 \mathrm{nmol} / \mathrm{l})$ compared to the more nervous lambs $(8.07 \mathrm{nmol} / \mathrm{l})$. The calm lambs had lower $(P<0.05)$ non-esterified fatty acid $(0.37 \mathrm{mmol} / \mathrm{l})$, cholesterol $(1.44 \mathrm{mmol} / \mathrm{l})$ and glucose $(3.29 \mathrm{mmol} / \mathrm{l})$ and higher triglyceride $(0.98 \mathrm{mmol} / \mathrm{l})$ concentrations and daily weight gain $(447.45 \mathrm{~g} /$ day) compared to the excitable ones $(0.81$, $1.86,4.14,0.57 \mathrm{mmol} / \mathrm{l}$ and $366.84 \mathrm{~g} /$ day). These data prove that an increased temperament score, through the higher cortisol concentration, has a great effect on the lambs' energy metabolic profile, which influences the fattening performance.
\end{abstract}

Keywords: Tsigai breed, temperament, cortisol concentration, lamb, energy metabolites, fattening

Abbreviations: HPA: hypothalamic-pituitary-adrenal, NEFA: non-esterified fatty acid

Archiv Tierzucht 56 (2013) 56, 573-580

doi: 10.7482/0003-9438-56-056

Corresponding author:

Ferenc Pajor; email: pajor.ferenc@mkk.szie.hu

Institute of Animal Husbandry, Szent István University, Pater Karoly 1, Godollo, 2103, Hungary

๔ 2013 by the authors; licensee Leibniz Institute for Farm Animal Biology (FBN), Dummerstorf, Germany This is an Open Access article distributed under the terms and conditions of the Creative Commons Attribution 3.0 License

(http://creativecommons.org/licenses/by/3.0/).

Received: 14 June 2012 Accepted: 19 March 2013 Online: 26 April 2013 


\section{Introduction}

The temperament of animals is a research area with increasing interest in animal breeding. Temperament is defined as the animal's behavioural response to handling by humans (Burrow 1997). It is well-known that the temperament of animals is affected by various factors such as breed, sire and age (Burrow 1997, Broucek et al. 2003). Nevertheless, some authors (such as Pajor et al. 2008) did not find significant differences between the temperament of ram and ewe lambs during fattening.

The nervous temperament has negative impacts on growth rate (Voisinet et al. 1997, Pajor et al. 2008), milk yield (Ivanov \& Djorbineva 2003, Pajor et al. 2010), meat and milk quality (Reverter et al. 2003, Orbán et al. 2011).

The temperament has been associated with cortisol concentrations in adult animals. In cattle (King et al. 2006, Curley et al. 2006) and in sheep (Pajor et al. 2010), restless nervous animals have greater cortisol concentrations. The results of the previous suggest that more temperamental ewes had higher baseline cortisol concentrations (Pajor et al. 2010). The hypothalamic-pituitary-adrenal (HPA) axis affects the animals' metabolism through the cortisol concentration because of increased catabolic processes (Brockman \& Laarveld 1986).

Although the majority of studies report relationships between the temperament of animals and production traits (such as weight gain) and with the blood cortisol concentration, still little is known about the background of this relationship between blood cortisol concentration, energy metabolism and temperament in lambs during fattening.

This aim of this study was to investigate the relationship between temperament score, stress hormone (cortisol) in blood and energy metabolic parameters (glucose, triglyceride, cholesterol and non-esterified fatty acid) as well as live weight and average daily weight gain of Tsigai lambs during fattening.

\section{Material and methods}

\section{Experimental design}

The study was carried out on a sheep farm in Solt (Bács-Kiskun County, Hungary). Thirtyone Tsigai single lambs (ram: $n=16$, ewe: $n=15$ ) were taken into fattening and scored using a temperament test. The fattening period lasted 41 days. During the fattening, lambs were given ad libitum water and concentrate mix $(150 \mathrm{~g} / \mathrm{kg}$ dry matter crude protein and $7.20 \mathrm{MJ} / \mathrm{kg}$ dry matter and $4.80 \mathrm{MJ} / \mathrm{kg}$ dry matter net energy $\left[\mathrm{NE}_{\mathrm{m}}\right.$ and $\left.\mathrm{NE}_{\mathrm{g}}\right]$ ). The lambs were kept in confinement on deep bedding ( $1 \mathrm{~m}^{2}$ per lamb) throughout the whole feeding period. The health status of animals was good during the experimental period. Each lamb was weighed individually with a precision of $0.1 \mathrm{~kg}$ at weaning and at the end of fattening. Daily weight gain was calculated in grams. In favour of adequate results, all lambs had identical genetic potential (all lambs originated from the same sire), keeping and feeding conditions.

Based on temperament score, 7 calm (1 score), 6 intermediate ( 3 score) and 7 nervous (poor temperament) lambs (4 and 5 scores) were randomly selected from a pool of 31 lambs for the analysis of blood parameters. Totally, the data of 9 rams and 11 ewes were analysed. Mean age and live weight of these lambs were 88 days and $20.9 \mathrm{~kg}$ (rams: $20.7 \mathrm{~kg}$; ewes: $21.0 \mathrm{~kg}$ ) at the beginning of fattening, while mean live weight and daily weight gain were 
$37.45 \mathrm{~kg}$ (rams: $37.9 \mathrm{~kg} ;$ ewes: $37.1 \mathrm{~kg}$ ) and $403.7 \mathrm{~g} /$ day (rams: $418.5 \mathrm{~g} /$ day; ewes: $391.6 \mathrm{~g} /$ day) at the end of fattening.

\section{Temperament test}

The temperament of lambs was evaluated twice with a temperament score test at the first and last days of fattening. Temperament was measured according to the temperament score test by Trillat et al. (2000). The behaviour of animals was recorded by a 5 -score system at weighing, while spending $30 \mathrm{sec}$ on the scale: 1 (calm, no movement), 2 (calm with occasional movements), 3 (calm with a bit more movement, but without shaking the scale), 4 (abrupt episodic movements without shaking the scale) and 5 (permanent episodic movements and shaking the scale).

\section{Analytical procedures}

Blood samples were collected from randomly selected Tsigai lambs $(n=20)$ at the beginning and the end of the fattening period, after temperament scoring from $v$. jugularis between $8^{00}-9^{00}$ hours. The blood samples were taken into 2 tubes: one containing heparin for cortisol and glucose analysis (from plasma), and another one without added anticoagulant for lipid metabolites (from serum). The blood sampling lasted approx. 0.5-1 min per animal. Then, samples were immediately transported to the laboratory and centrifuged at $3500 \mathrm{l} / \mathrm{min}$ for $10 \mathrm{~min}$. The plasma and serum were stored at $-70^{\circ} \mathrm{C}$ until further analyses.

\section{Cortisol}

For the cortisol assay a direct radioimmunoassay method developed in the laboratory of Szent Istvan University, Faculty for Veterinary Science (Budapest, Hungary) was applied. For determining the cortisol level in blood plasma, we have used 1,2,6,7-[ $\left.{ }^{3} \mathrm{H}\right]$-cortisol (TRK 407; Radiochemical Centre, Amersham, UK) and a highly specific polyclonal antibody raised against cortisol-21-HS-BSA in rabbit. Radioactivity was measured with a Tri-Carb 2800TR (Perkin-Elmer) liquid scintillation counter. The sensitivity of this assay system was $11.37 \mathrm{fmol} /$ tube. Within the concentration range of about 2.00 and $100.00 \mathrm{nmol} / \mathrm{ml}$ the intra- and interassay coefficients of variation varied between $3-8 \%$ and $5-10 \%$, respectively in all species. Samples with a cortisol level being higher than $100.00 \mathrm{nmol} / \mathrm{l}$ had to be re-assayed after dilution.

\section{Glucose}

The glucose was analysed with an enzymatic-colorimetric method using commercial kits (Diagnosticum Zrt, Budapest, Hungary).

\section{Non-esterified fatty acid, triglyceride and cholesterol}

The non-esterified fatty acid, triglyceride and cholesterol levels were analysed with an enzymatic-colorimetric method using commercial kits (NEFA kit, Randox test kit, Randox Laboratories, Cork, Ireland; triglyceride and cholesterol kits, colorimetric test kit, Diagnosticum Zrt., Budapest, Hungary). 


\section{Statistical analysis}

Effects of temperament and gender were analysed as independent variables. Statistical analysis was processed by the SPSS 14.0 programme package (Shapiro-Wilk test for normality distribution, F and t-test, Levene's test for equality of Variances, ANOVA, LSD test, Spearman correlation).

\section{Results}

\section{Basic parameters}

Temperament score, plasma cortisol and glucose concentrations and serum non-esterified fatty acid, cholesterol and triglyceride concentrations of lambs are presented in Table 1.

Table 1

Temperament score and blood parameters of Tsigai lambs during fattening period (mean \pm SD)

\begin{tabular}{lcc}
\hline Investigated traits & \multicolumn{2}{c}{ Stage of fattening } \\
\hline Temperament, score & Day 1 & Day 41 \\
Cortisol, $\mathrm{nmol} / \mathrm{l}$ & $2.78 \pm 1.44$ & $2.89 \pm 1.23$ \\
Non-esterified fatty acid, mmol/l & $2.61 \pm 1.24^{\mathrm{a}}$ & $4.83 \pm 3.49^{\mathrm{b}}$ \\
Triglyceride, $\mathrm{mmol} / \mathrm{l}$ & $0.11 \pm 0.05^{\mathrm{a}}$ & $0.62 \pm 0.37^{\mathrm{b}}$ \\
Cholesterol, $\mathrm{mmol} / \mathrm{l}$ & $0.77 \pm 0.35$ & $0.69 \pm 0.25$ \\
Glucose, $\mathrm{mmol} / \mathrm{l}$ & $1.45 \pm 0.38$ & $1.61 \pm 0.35$ \\
\hline
\end{tabular}

${ }^{\text {ab }} P<0.05$, different letters in a row denote significant differences

The fattening parameters, temperament scores and analysed blood parameters of lambs were not affected by the gender in any of the observations (not presented in Table 1). The cortisol and non-esterified fatty acid concentrations of the lambs tended to increase towards the end of the fattening period. The opposite trend was found for the glucose concentration. Significant differences were found neither between these and the temperament scores nor between the triglyceride and cholesterol concentrations of lambs.

\section{Cortisol concentration and temperament}

The blood cortisol concentrations and temperament scores of lambs are shown in Table 2 .

The temperament scores did not reveal any relation with cortisol concentration at the beginning of fattening but this parameter showed a high difference between temperament score categories at the end of fattening. Highly significant differences in cortisol concentration change were detected in nervous lambs during the studied period (from $2.10 \mathrm{nmol} / \mathrm{l}$ to $8.07 \mathrm{nmol} / \mathrm{l} ; P<0.05$ ), which means an increase of $384 \%$. At the same time, there was no significant increase between the two treatments neither the calmer nor the intermediate lambs.

At the end of fattening, the calmer lambs had a lower cortisol concentration $(2.60 \mathrm{nmol} / \mathrm{l})$ compared to the nervous lambs $(8.07 \mathrm{nmol} / \mathrm{l})$. Moreover, the lambs' temperament score was highly related to the cortisol concentration $\left(r_{\text {rank }}=0.81, P<0.001\right.$; data not shown). 
Table 2

Blood cortisol concentration and temperament scores of Tsigai lambs (mean \pm SD)

\begin{tabular}{lccc}
\hline Investigated traits & \multicolumn{3}{c}{ Temperament $^{*}$} \\
& $\mathrm{n}=7$ & $\begin{array}{c}\text { calm (1) } \\
\text { intermediate (3) } \\
\mathrm{n}=6\end{array}$ & $\begin{array}{c}\text { nervous (4+5) } \\
\mathrm{n}=7\end{array}$ \\
\hline Temperament score, day 1 & $1.00 \pm 0.00$ & $3.00 \pm 0.00$ & $4.33 \pm 0.52$ \\
Temperament score, day 41 & $2.00 \pm 0.89^{\mathrm{a}}$ & $2.50 \pm .084^{\mathrm{a}}$ & $4.17 \pm 0.75^{\mathrm{b}}$ \\
Cortisol, nmol/l, day 1 & $2.99 \pm 1.09$ & $2.73 \pm 1.73$ & $2.10 \pm 0.72$ \\
Cortisol, nmol/l, day 41 & $2.60 \pm 1.92^{\mathrm{a}}$ & $3.81 \pm 1.62^{\mathrm{a}}$ & $8.07 \pm 3.93^{\mathrm{b}}$ \\
Corisol change - $P$ & $\mathrm{~ns}$ & $\mathrm{~ns}$ & $<0.05$ \\
\hline
\end{tabular}

*Based on scoring at beginning of fattening - 1: calm, no movement, 3: calm with some more movements but without shaking the scale; 4: abrupt episodic movements without shaking the scale, 5: permanent episodic movements and shaking the scale, ${ }^{a b} P<0.05$, different letters in a row denote significant differences, ns: not significant

\section{Energy metabolic profile}

The blood metabolic profile of Tsigai lambs by temperament is shown in Table 3 .

Table 3

Blood metabolic profile of Tsigai lambs by temperament categories (mean \pm SD)

\begin{tabular}{|c|c|c|c|}
\hline \multirow[t]{2}{*}{ Investigated traits } & \multicolumn{3}{|c|}{ Temperament ${ }^{*}$} \\
\hline & $\begin{array}{c}\text { calm (1) } \\
\mathrm{n}=7\end{array}$ & $\begin{array}{l}\text { intermediate (3) } \\
\mathrm{n}=6\end{array}$ & $\begin{array}{c}\text { Nervous }(4+5) \\
n=7\end{array}$ \\
\hline \multicolumn{4}{|l|}{ Day 1} \\
\hline $\mathrm{NEFA}, \mathrm{mmol} / \mathrm{l}$ & $0.12 \pm 0.05$ & $0.12 \pm 0.07$ & $0.09 \pm 0.02$ \\
\hline Triglyceride, $\mathrm{mmol} / \mathrm{l}$ & $0.70 \pm 0.31$ & $0.91 \pm 0.51$ & $0.71 \pm 0.14$ \\
\hline Cholesterol, $\mathrm{mmol} / \mathrm{l}$ & $1.54 \pm 0.62$ & $1.34 \pm 0.16$ & $1.46 \pm 0.23$ \\
\hline Glucose, $\mathrm{mmol} / \mathrm{l}$ & $4.17 \pm 0.31$ & $3.90 \pm 0.18$ & $4.19 \pm 0.23$ \\
\hline \multicolumn{4}{|l|}{ Day 41} \\
\hline $\mathrm{NEFA}, \mathrm{mmol} / \mathrm{l}$ & $0.37 \pm 0.33^{\mathrm{a}}$ & $0.64 \pm 0.29$ & $0.81 \pm 0.37^{\mathrm{b}}$ \\
\hline Triglyceride, $\mathrm{mmol} / \mathrm{l}$ & $0.98 \pm 0.24^{\mathrm{a}}$ & $0.55 \pm 0.15^{b}$ & $0.57 \pm 0.07^{b}$ \\
\hline Cholesterol, $\mathrm{mmol} / \mathrm{l}$ & $1.44 \pm 0.29^{\mathrm{a}}$ & $1.86 \pm 0.23^{b}$ & $1.50 \pm 0.42$ \\
\hline Glucose, mmol/l & $3.29 \pm 0.44^{\mathrm{a}}$ & $3.53 \pm 0.88$ & $4.14 \pm 0.49^{b}$ \\
\hline
\end{tabular}

*Based on scoring at beginning of fattening - 1: calm, no movement, 3: calm with some more movements but without shaking the scale; 4: abrupt episodic movements without shaking the scale, 5: permanent episodic movements and shaking the scale, ab $P<0.05$, different letters in a row denote significant differences

At the beginning of fattening, there were no detectable differences in the serum nonesterified fatty acid, triglyceride, cholesterol and glucose concentrations of lambs getting different temperament scores (when measured at the end of fattening). On the contrary, the blood metabolic parameters showed high differences among temperament scores. The calm lambs had lower $(P<0.05)$ non-esterified fatty acid $(0.37 \mathrm{mmol} / \mathrm{l})$, cholesterol $(1.44 \mathrm{mmol} / \mathrm{l})$ and glucose concentrations $(3.29 \mathrm{mmol} / \mathrm{l})$ as well as higher triglyceride $(0.98 \mathrm{mmol} / \mathrm{l})$ concentrations compared to the more excitable lambs $(0.81,1.86,4.14$ and $0.57 \mathrm{mmol} / \mathrm{l})$. 


\section{Lamb performance}

The fattening traits of Tsigai lambs by temperament scores are presented in Table 4.

Table 4

Fattening traits of Tsigai lambs by temperament categories (mean \pm SD)

\begin{tabular}{|c|c|c|c|}
\hline \multirow[t]{2}{*}{ Investigated traits } & \multicolumn{3}{|c|}{ Temperament ${ }^{*}$} \\
\hline & $\begin{array}{c}\text { calm (1) } \\
n=7\end{array}$ & $\begin{array}{l}\text { intermediate (3) } \\
\qquad n=6\end{array}$ & $\begin{array}{c}\text { nervous }(4+5) \\
n=7\end{array}$ \\
\hline \multicolumn{4}{|l|}{ Day 1} \\
\hline Live weight, kg & $20.33 \pm 1.79$ & $20.83 \pm 1.68$ & $20.82 \pm 1.23$ \\
\hline Preweaning weight gain, g/day & $236.73 \pm 28.04$ & $236.73 \pm 19.09$ & $236.63 \pm 13.99$ \\
\hline \multicolumn{4}{|l|}{ Day 41} \\
\hline Live weight, kg & $38.67 \pm 1.06^{a}$ & $38.05 \pm 1.93$ & $35.82 \pm 1.03^{b}$ \\
\hline Postweaning weight gain, g/day & $447.15 \pm 36.72^{\mathrm{a}}$ & $419.92 \pm 46.13^{a}$ & $366.84 \pm 25.42^{b}$ \\
\hline
\end{tabular}

*Based on scoring at beginning of fattening -1 : calm, no movement, 3: calm with some more movements but without shaking the scale; 4: abrupt episodic movements without shaking the scale, 5: permanent episodic movements and shaking the scale, ${ }^{\text {ab }} P<0.05$, different letters in a row denote significant differences.

The temperament did not affect the live weight at the beginning of fattening and the weight gain during the rearing period but traits connected to growing showed a high difference among temperament categories at the end of fattening. The calm lambs had a higher live weight $(38.67 \mathrm{~kg})$ and daily weight gain $(447.15 \mathrm{~g} / \mathrm{day})$ at the end of the studied period compared to the nervous lambs $(35.82 \mathrm{~kg}, 366.84 \mathrm{~g} / \mathrm{day} ; P<0.05)$.

\section{Discussion}

Values of investigated blood parameters are within the normal ranges for ruminants reported by Forbes et al. (1998). The cortisol concentration may depend on sampling circumstances. Particular treatment can be measured if a blood sample is collected within 2 min from the beginning of the blood sampling procedure (Broom \& Johnson 1993). The sampling procedure lasts less than $2 \mathrm{~min}$. Therefore, the sampling circumstances did not modify the characteristic cortisol values of the animals. Furthermore, the baseline cortisol values in cattle reported by Grandin (1997) are in concordance with the range our study shows for this parameter.

At the beginning of fattening, the temperament scores were not related to the cortisol concentrations because before weaning, as expected, the behaviour of lambs is affected by maternal factors such as dam-lamb bond. On the contrary, at the end of the trial the cortisol concentrations were highly related to the temperament scores of the lambs. The calm lambs (score 1) had a significantly lower cortisol concentration compared to the nervous animals (scores 4 and 5). The post-weaning performance and individual traits (such as behaviour) are influenced by the individual genetic potentials of the lambs and the environmental circumstances. It is verified, that the temperament is an inheritable trait. The estimated heritability of temperament in sheep is around 0.26 (Martin et al. 2004) and the repeatability is good (0.32, Lambe et al. 2001). 
Plasma glucose concentration decreased during our research. At the time of weaning, the results were close to non-ruminant species but at the end of fattening they reached the typical level of ruminants in accordance with the results of Norouzian \& Valizadeh (2011). Moreover, at the end of fattening the concentrations of NEFA and glucose increased and triglycerides decreased in the more temperamental lambs. The high concentration of NEFA indicates an adrenergic stimulus of lipolysis and fat mobilization. On the other hand, the reduction of triglycerides was observed in the nervous lambs. The lower values could be due to an increase in lipid utilization by the peripheral tissues and conversion of triglycerides into glycerol and NEFA. The increased cortisol concentration in plasma, associated with the inhibition of glucose uptake in muscle and adipose tissues and finally insulin resistance (Stratakis et al. 1995), caused higher glucose concentrations in nervous animals. The HPA axis affects the metabolism of animals through the cortisol concentration (Gupta et al. 2004). The regulation of HPA axis and its impact on metabolism and animal welfare is summarized in a review report by Manteuffel (2002). One of the biological responses means increased catabolic processes, such as increased lipolysis (Brockman \& Laarveld 1986). The higher baseline cortisol inhibits energy metabolism by altering the function of the HPA axis. Insufficiency of energy metabolism causes decreased efficiency of nutrient utilization (e.g. residual feed intake) (Knott et al. 2007). As a summary, deficiency of energy metabolic parameters had a negative effect on weight gain and live weight of lambs. This could cause that nervous lambs grow slower during fattening period and reach a lower live weight at the end of fattening than calm lambs. Similar findings have been reported by Voisinet et al. (1997), Fell et al. (1999) and Pajor et al. (2011), where more temperamental cattle and lambs had a lower live weight and average daily weight gain during fattening but they did not investigate the relationship between energy metabolism parameters and the temperament of animals.

In conclusion, an increased temperament score through the higher cortisol concentration has a negative effect on the energy metabolic profile of lambs and is connected with worse fattening traits. These results demonstrate that temperament has a high impact on the growing ability of lambs during fattening. It should be noted that before using temperament as an indirect selection criterion for improving production traits, more work is needed to identify the accurate correspondence between profitability and temperament of animals.

\section{Acknowledgements}

This work was supported by TAMOP Project (TÁMOP-4.2.1.B-11/2/KMR-2011-0003). We appreciate and we would like to say thank for assistance of Prof. Dr. Huszenicza Gyula ${ }^{\dagger}$ (cortisol determination) (SZIU-FVS).

\section{References}

Brockman RP, Laarveld B (1986) Hormonal regulation of metabolism in ruminants; a review. Livest Prod Sci 14, 313-334

Broucek J, Kisac P, Uhrincat M (2003) The effect of sire line on learning and locomotor behaviour of heifers. Czech J Anim Sci 48, 387-394

Broom DM, Johnson KG (1993) Stress and Animal Welfare. Chapman and Hall, London, UK 
Burrow HM (1997) Measurement of temperament and their relationship with performance traits of beef cattle. Anim Breed Abstr 65, 478-495

Curley Jr KO, Neuendorff DA, Lewis AW, Cleere JJ, Welsh Jr TH, Randel RD (2008) Functional characteristics of the bovine hypothalamic-pituitary-adrenal axis vary with temperament. Horm Behav 53, 20-27

Fell LR, Colditz IG, Walker KH, Watson DL (1999) Associations between temperament, performance and immune function in cattle entering a commercial feedlot. Aust J Exp Agr 39, 795-802

Forbes CD, Fernandez JM, Bunting LD, Southern LL, Thompson Jr DL, Gentry LR, Chapa AM (1998) Growth and metabolic characteristics of Suffolk and Gulf Coast Native yearling ewes supplemented with chromium tripicolinate. Small Rumin Res 28, 149-160

Grandin T (1997) Assessment of stress during handling and transport. J Anim Sci 75, 249-257

Gupta S, Earley B, Ting STL, Leonard N, Crowe MA (2004) Technical Note: Effect of corticotropin-releasing hormone on adrenocorticotropic hormone and cortisol in steers. J Anim Sci 82, 1952-1956

Dimitrov-Ivanov I, Djorbineva M (2003) Assessment of welfare, functional parameters of the udder, milk productive and reproductive traits in dairy ewes of different temperament. Bulg J Agric Sci 9, 707-711

King DA, Schuehle Pfeiffer CE, Randel RD, Welsh Jr TH, Oliphint RA, Baird BE, Curley Jr KO, Vann RC, Hale DS, Savell JW (2006) Influence of animal temperament and stress responsiveness on the carcass quality and beef tenderness of feedlot cattle. Meat Sci 74, 546-556

Knott SA, Cummins LJ, Dunshea FR, Leury BJ (2007) Rams with poor feed efficiency are highly responsive to an exogenous adrenocorticotropin hormone (ACTH) challenge. Domest Anim Endocrinol 34, 261-268

Lambe NR, Conington J, Bishop SC, Waterhouse A, Simm G (2001) A genetic analysis of maternal behaviour score in Scottish Blackface sheep. Anim Sci 72, 415-425

Manteuffel G (2002) Central nervous regulation of the hypothalamic-pituitary-adrenal axis and its impact on fertility, immunity, metabolism and animal welfare - a review. Arch Tierz 45, 575-595

Martin GB, Milton JTB, Davidson RH, Banchero Hunzicker GE, Lindsay DR, Blache D (2004) Natural methods for increasing reproductive efficiency in small ruminants. Anim Reprod Sci 82-83, 231-245

Norouzian MA, Valizadeh R (2011) Effect of rearing system on pre-weaning growth, rumen development and its influence on post-weaning performance of lambs. Arch Tierz 54, 525-534

Orbán M, Kovácsné Gaál K, Pajor F, Szentléleki A, Póti P, Tőzsér J, Gulyás L (2011) Effect of temperament of Jersey and Holstein Friesian cows on milk production traits and somatic cell count. Arch Tierz 54, 594-599

Pajor F, Szentléleki A, Láczó E, Tőzsér J, Póti P (2008) The effect of temperament on weight gain of Hungarian Merino, German Merino and German Blackhead lambs. Arch Tierz 51, 247-254

Pajor F, Murányi A, Szentléleki A, Tőzsér J, Póti P (2010) Effect of temperament of ewes on their maternal ability and their lambs' postweaning traits in Tsigai breed. Arch Tierz 53, 465-474

Pajor F, Szentléleki A, Tőzsér J, Póti P (2011) [Effect of German Merino lambs' temperament at weaning on certain fattening traits]. Anim Welf Etol Tartástechn 7, 59-70 [in Hungarian]

Reverter A, Johnston DJ, Ferguson DM, Perry D, Goddard ME, Burrow HM, Oddy VH, Thompson JM, Bindon BM (2003) Genetic and phenotypic characterisation of animal, carcass and meat quality traits from temperate and tropically adapted beef breeds. 4. Correlations among animal, carcass and meat quality traits. Aust J Agric Res 54, 149-158

Stratakis CA, Gold PW, Chrousos GP (1995) Neuroendocrinology of Stress: Implications for Growth and Development. Horm Res Paediatr 43, 162-167

Trillat G, Boissy A, Boivin X, Monin G, Sapa J, Mormende P, Le Neindre P (2000) [Relations between the wellbeing of cattle and meat characteristics. Final Report June]. INRA, Theix, France 1-33 [in French]

Voisinet BD, Grandin T, Tatum JD, O'Connor SF, Struthers JJ (1997) Feedlot cattle with calm temperaments have higher average daily gains than cattle excitable temperaments. J Anim Sci 75, 892-896 